\title{
Em busca do tempo de Alceu
}

\section{Marcos Cotrim de Barcellos}

MENDES, Candido. Dr. Alceu: da "persona" à pessoa. São Paulo: Paulinas, 2008.

Alceu Amoroso Lima (1893-1983) foi um dos principais pensadores sociais da cena brasileira no século passado, com interesses que vão das questôes políticas às econômicas e culturais, para cujo tratamento trouxe uma perspectiva assinalada por sua fé católica e sua irrenunciável vocação de crítico literário. Professor na Faculdade Nacional de Filosofia (hoje UFRJ), escritor com mais de oitenta títulos publicados, membro da Academia Brasileira de Letras, cofundador da Pontifícia Universidade Católica do Rio de Janeiro, é hoje mais lembrado pela defesa que fez dos direitos civis nos tempos do Regime Militar. Jornalista que também era, ficou mais conhecido do grande público pelo pseudônimo, Tristão de Athayde.

Trazendo a data que recorda a morte de Amoroso Lima há um quarto de século, e surgindo neste 2009, ano que assinala os noventa anos de estreia de Tristão de Athayde, o livro do professor Candido Mendes tem atributos para tornar-se referência importante para todos que desejarem se aprofundar no campo das interpretaçôes do Brasil.

Candido Mendes vale-se do olhar do próprio Tristão de Athayde - espectador privilegiado do diálogo entre fé e razão na cultura do século XX e ator no cenário que confrontou literatura, religião e política no Brasil -, para oferecer uma narrativa situada no mundo revolucionado em que Alceu "toma a palavra". Mendes junta, com autoridade de "herdeiro espiritual", à bibliografia a respeito de um dos mais importantes pensadores católicos contemporâneos, este relato do desenvolvimento, mais que biográfico, de uma visão de mundo. Deixa nele patente a admiração pelo homenageado, sem ceder no empenho pelo descrever preciso a que o conduz sua erudiçâo, aliada ao conhecido estilo que permanentemente desafia o leitor.

Entre os títulos publicados por Candido Mendes, em que se destacam temas relativos à liberda- de no mundo contemporâneo, encontra-se o viés teórico que em parte explica a envergadura do livro aqui resenhado: a abordagem ética, ao mesmo tempo humanista e confessional, do mundo da política, em suas expressões sociais, econômicas, ambientais ou jurídicas. O problema de uma coexistência pacífica das diferenças, tantas vezes exacerbadas com vezo pluralista, é trazido seguidamente à pauta de uma constatação do caráter globalizado, intrincado, dessas questôes comuns a todos os homens. Títulos sobre a democracia, o progresso, a educação, a Igreja versus populum, o diálogo das culturas, o ecumenismo, acham-se ao lado de duas obras jubilares sobre o "Dr. Alceu", publicadas em 1984 e 1994 . O ritmo de Dr. Alceu: da "persona" à pessoa traz este testemunho, o de um escrito que se faz mais a partir do personagem evocado do que sobre ele, equilibrando-se entre a urgência dos problemas que espicaçam a consciência e a disponibilidade ao mistério, que Mendes procura valorizar mediante o arejamento confessadamente "pós-moderno" de sua abordagem.

Os seis capítulos do livro aparecem como superposições de tomadas que tentam enquadrar o personagem sem reduzi-lo ao script historiográfico vida-obra-pensamento, mas sem privar o leitor do efeito didático dessa técnica. Tristão dá a perspectiva que domina a observância do convertido, com sua ortodoxia militante; dá identidade às transformaçôes que levaram Alceu nos caminhos da sensibilidade à questão social, do engajamento político, do testemunho solicitado pelos "sinais dos tempos". A "toma da palavra" por Alceu alarga a cena e dimensiona a estatura do personagem para além da récita, sob o olhar do crítico.

Intérprete, Mendes mostra como a integração de vida, fé e pensamento aí subsiste como a força de um sentido, categoria com que matiza a trajetória de Alceu, convertido de 1928, e capta as nuanças que entregaram o coração desse admirador de Jackson de Figueiredo à fé do confidente de Leonel Franca e à inteligência do leitor de Ja- 
cques Maritain. Quem teria dado o tom do acorde capaz de, se não evitar, moderar o integrismo do Alceu cultor da ordem fora um Tristão seu preceptor. Perceber a inquietação de Pascal, o processo da vida de Bergson, a excelência do pequeno de Chesterton, a terceira via de Mounier, o mistério de Gabriel Marcel, o insight de Lonergan, a recepção de Jauss, é uma das chaves de entrada do texto, na medida em que dá sentido histórico àquilo que poderia ser visto como simplificação do perfil de um Alceu fiel ao magistério ultramontano dos papas, fundador da Ação Católica e da LEC (Liga Eleitoral Católica), debatedor do modernismo de 1922 e dos pioneiros de 1932.

Candido Mendes evita, porém, que a ultrapassagem da pecha de conservador pelas audácias do "libertário" seja recebida pelo leitor como um abandono das altas causas que abonam o caráter do homenageado, usando expressões que só aos poucos se sedimentaram no discurso de Alceu. Mendes explica que aquele, "atento ao sinal dos tempos", viu-se amparado pela percepção de que deveria "romper com a pequena ordem em busca da grande ordem" (p. 75). Não como uma posição meramente teórica, mas pelo discernimento existencial de que "a Igreja não é legionária mas missionária” (p. 77). A relevância da observação fica realçada quando se recorda que a Igreja católica estava mobilizada no século XX pelas estratégias de "romanização", centralizando seu magistério no Papado por meio de um processo de clericalização das praxes de piedade e da revisão sistemática do chamado "catolicismo popular" herdado das tradiçôes coloniais. Esse catolicismo de "reação", antiliberal, antiprotestante, muitas vezes de tom condenatório e moralista, em contínua suspeita em face da modernidade, aparece no livro como a atmosfera do mundo em que Alceu se converteu e no qual o escritor diletante deu "adeus à disponibilidade" na década de 1920 . A revisão dos valores desse mundo será tanto objeto quanto perspectiva no texto de Mendes.

Nesta medida, a "toma da palavra" por Alceu é descrita mais como testemunho do que como discurso politicamente correto à cata de uma práxis oportunamente aggiornata. $\mathrm{O}$ autor atribui à ortodoxia do seu "olhar sobre a totalidade" o condão de fundir existencialmente transcendência e histó- ria no protagonismo do Alceu que, embora "católico pletórico" (p. 128), teria, no decorrer de seu processo de síntese pessoal, evitado agir com a "veleidade de partir de uma tese" (p. 131).

Em sua busca do tempo do Dr. Alceu, Candido Mendes serve-se do tema da viagem nos dois primeiros capítulos, em que recorre ao tópico bíblico da transformação do "homem velho" em "homem novo", misturando percursos interiores com excursōes concretas, alinhando produção intelectual, inserção política e publicações especialmente representativas do homem de letras. Por isso pega-nos desprevenidos, o enquadramento crítico de Alceu no capítulo III, A Representação da Realida$d e$. De fato, seria mais fácil ceder à naturalização da tese promovida pela vertigem do ritmo narrativo, a chancelar o "grande récito" do herói católico pelo reforço do estereótipo, cuidadosamente evitado pela sobriedade que permeia o painel da obra do intelectual engajado.

Aqui torna-se claro um dos motes do livro, uma quiçá irônica descoberta do outro. O olhar de Tristão é apresentado defrontando-se com o "outro Brasil", descoberto nos sertōes, desde a "ética fundadora de Euclides" até a programática Introdução ao livro sobre Afonso Arinos (1922), como rito de passagem de Alceu, rito de "descida ao histórico concreto". Observa Mendes que "no Ursprung de Tristão, a disciplina da subjetividade na 'abertura do outro', e na reta intenção do crítico, permitiria chegar-se por acréscimo a todos os demais" (p. 251). O outro será o epicentro da "grande ordem" que vai conformando o Alceu maduro, abrindo-o a uma realidade mais histórica, menos mediada pelo formalismo, pela "luxúria da cabeça", que teria gerado nele o "eu-de-serviço".

Tal abertura é descrita como uma dialética em que Alceu é levado por Tristão a se defrontar com Alberto Torres, Oswald de Andrade, Sérgio Buarque de Holanda, Graça Aranha, em meio aos abalos que "sacudiram o Parnaso" nacional em 1922, lançando mão de uma "pedagogia do susto e da quebra" (p. 268). Ao formar seu critério de leitura da realidade cultural (uma então moderna "crítica expressionista"), transcendendo o padrão de Hippolyte Taine (meio-raça-momento) e dialogando com Sílvio Romero, Tristão teria posto em marcha a saga de Alceu em busca de seu pró- 
prio tempo. Como relacionar estética modernista e catolicismo romanizado? Descoberta do Brasil brasileiro e invocação da razão clássica? "Abertura à surpresa do concreto" e assentamento do discurso sobre a "instauração metafísica da vida na ordem" (p. 271)? Mendes esclarece o ponto, citando o testemunho-síntese de um Alceu maduro, datado de 1952, pelo qual não haveria contradição entre ser "católico em religião, tomista em filosofia, democrata em política e modernista em arte. Nem antimodernista porque católico como Jackson; nem anticatólico, porque modernista como Mário de Andrade. Ao contrário, católico e moderno em arte" (p. 271).

O capítulo III prossegue depurando a imagem do Dr. Alceu de possíveis assédios da retórica canonizadora da persona, submetendo-a ao crivo pelo qual Charles Péguy faz passar "o mundo da burguesia triunfante", à atmosfera da mouvance de Marcel Proust, com sua anamnese criadora ("O referencial a Proust vai urdir no fundo do espírito de Alceu outra dessas fieiras secretas de todo seu percurso intelectual”, diz Mendes à p. 275), às mediações do vivido nas rotinas desgastadas pelo absoluto, que lhe proporciona Gabriel Marcel. O autor faz questão de mostrar que desde o início, o olhar de Alceu firma-se sobre a mirada fenomenológica sempre resguardada no percurso, onde "encontra-se o segredo de sua reflexão", capaz de moderar-lhe a sedução analítica do cogito (p. 283).

Entre o jornalista da disponibilidade elegante da belle époque e o escritor universal forjado pelo neotomismo, Mendes lança a ponte da cultura filosófica, teológico-política, protagonizada por Jackson de Figueiredo - com sua Livraria Católica e o caudal apologético que conflui no Centro Dom Vital e na revista $A$ Ordem - e pelo "Cardeal sutil", Dom Sebastião Leme, revelando interlocutores fundamentais na síntese de Alceu. Com eles e por eles, tomam da palavra o sociólogo, o articulista, o panegirista, o memorialista, cada qual em seu desempenho, discernidos pelo autor ao longo do capítulo.

A rotina do cogito escolástico, indo das formas concebidas pelo crítico para as ideias esgrimidas pelo erudito, e destas para os acontecimentos percebidos pelo analista de conjunturas, para voltar dialeticamente aos universais garimpados na cultura e na história, dá à "representação da realida- de" o endereço da "conversão" ao "eu-de-serviço". O leitor percebe melhor, a partir do quarto capítulo, uma espécie de definição de rumo do escrito, anunciando o desfecho em que o autor nos restituirá o católico libertário, mais social-democrata (clamando por "socialismo com justiça") do que democrata-cristão.

Mendes traça a trajetória dos “adeuses”, pontuada pelas estações que marcaram a vida de Alceu, observando que "a purga vai, de fato, à transposição das personas" (p. 354). Assevera, com efeito, que "o primeiro de nossos leigos" passara da "disponibilidade" ao enquadramento ontológico-normativo do "neotomismo engajado" e deste ao "novo adeus de 50", definido pelo "aporte das categorias de espera e presença” de um Marcel e pelo rasgo dos tempos que anunciavam o Concílio Vaticano II (p. 362).

Sob tal impressão, entra-se no capítulo $\mathrm{V}, \mathrm{Al}$ ceu pelos grandes contrastes, um mosaico formado pelas peças variadas do diálogo de Alceu com outros pensadores. $\mathrm{O}$ texto realça suas facetas universalista e humanista nas referências a Rui Barbosa, suas parcerias ora cordiais ora polêmicas com Jackson de Figueiredo, Sobral Pinto, Plínio Salgado e Gustavo Corção, e nos reporta o enfrentamento do estado de exceção militar, em que se faz voz contra a censura e a tortura, e o debate pelo espólio da Ação Católica. Corção, principalmente, é trazido ao plano do desencontro dos tempos, à fratura dos momentos dos dois convertidos, Alceu aberto à "terceira posição" da democracia cristã, e Corção apaixonado pelo distributivismo chestertoniano, também uma "terceira fórmula", mais ingenuamente utópica, e menos sensível aos sinais dos tempos, no dizer do autor. O juízo que o leitor dos quatro subcapítulos dedicados ao escritor de $A$ descoberta do outro pode ser levado a formar, sem ter lido $O$ desconcerto do mundo, faz quiçá desta estação do livro, alvo de algum reparo. Os apodos de "integrismo", "maniqueísmo" e outros conotativos reduzem desnecessariamente a estatura do Corção pensador ao papel de figurante na ribalta de um Alceu pedagogicamente apolíneo.

Melhor sorte tem Jacques Maritain, o "exegeta angélico", no desdobramento do capítulo. Posto o horizonte axiológico de uma práxis definida como "encarnação do Verbo na história", Mendes faz intervirem, ao lado do autor de Humanismo inte- 
gral, a fenomenologia de Paul Ricoeur e a doutrina social da Igreja, em sua exemplar formulação na constituição dogmática Gaudium et Spes, do Concílio Vaticano II (1962-1965). O "otimismo epifânico" de Alceu não se contentaria, porém, com o combate do progressismo maritainiano, exigindo a ultrapassagem dialética de uma liberdade em que retoma o senso histórico da práxis de um Teillard e a esperança de "mais-ser", que via confirmada no magistério do Concílio.

$\mathrm{O}$ autor descreve aqui o homem confrontado por Georges Bernanos com um "catolicismo definitivamente desinstalado da ordem" e capaz então de assumir as tarefas de leigo da Comissão Pontifícia Justiça e Paz no fim dos anos 1960 (p. 459). A estrela de Bernanos dá o sinal do encerramento do livro, cujo capítulo derradeiro, $A$ lição do eterno: Alceu e a Igreja, mais uma vez reinscreve o movimento da persona à pessoa anunciado nas palavras do próprio Alceu: "A verdade está sempre no âmago das pessoas e das coisas, e não nas suas aparências." A subjetividade do "pensador confessional", lançada no fio escatológico que identifica a "História a uma antropologia do mais-ser", seria então patrocinada pela "tensão fundamental do encontro da Igreja com o mundo" (p. 474). Aí, segundo Mendes, se dera a formação da perspectiva histórica de um Alceu que enfim se sabe mais "peregrino" orientado por sua "meia escatologia" do que ator escalado para um drama escrito a priori pelos cânones da abstração e o placet do estabilishment. De fato, a "profunda intuição do histórico concreto em Alceu vai salvá-lo dos esquematismos [...] de defesa da ordem da Cidade de Deus" (p. 479). $\mathrm{O}$ autor assinala, entretanto, que o papel de Alceu no fluxo desse movimento deve ser entendido pelas limitações de sua concepção de temporalidade, que "não alcança uma etiologia da História como advento das culturas" (p. 487), ainda que não se frustre no prognóstico dos desdobramentos do novo "humanismo cristão" evocado na Gaudium et Spes. As exigências missionárias requeriam, diz, um logos alinhado à filosofia do sujeito, que submetesse o cânon da perfectibilidade ao horizonte do empenho social transformador.

Postos o referencial da eclesiologia versus populum e as limitações da concepção de história de um Alceu fiel ao paradigma da "terceira via" (opção entre o comunismo totalitário e o capitalismo excludente), Mendes chama a atenção para suas intuiçôes sobre a fecundidade dos "movimentos" sociais, motivos de esperança ante a corrosão dos tecidos políticos convencionais denunciada nas Conferências Episcopais de Puebla e Medellín. As mesmas que o levaram a haver-se cautelosa, mas positivamente com o Partido dos Trabalhadores, a reforma agrária e o inopinado de uma interlocução pulverizada e marginalizada nas Comunidades Eclesiais de Base. A desconfiança para com as "elites", incapazes de uma efetiva "ação transformadora", tornara então iminente o último lance da "toma da palavra" de Tristão. Por este "buraco da agulha", Alceu teria sido então introduzido à derradeira liberdade, "desligado de todas as amarras" com que se havia prendido, o convertido de 1928.

Neste passo, Candido Mendes não deixa de tomar ele mesmo a palavra como herdeiro da missão do Dr. Alceu, ditando sobre os prognósticos do mestre, arrazoados a respeito do cenário dos despossuídos e excluídos de uma sociedade "da hiperorganização" que não pode deixar de ser também dos "superdescartes".

A proeminência da figura do Papa João XXIII nas páginas de encerramento do livro deixam a impressão de que a pessoa de Alceu, discretamente, teria ao fim tornado a palavra a Tristão, só ele capaz de ultrapassar o vigor analítico do olhar sobre os sujeitos históricos, reclamado por Mendes, com o aceno ao mistério como fulcro da busca da verdade. Neste diapasão, o autor parece deixar por responder a questão com que, em Meio século de presença literária, Amoroso Lima encerra uma Carta de Alceu a Tristão: "saber qual dos dois foi afinal o autêntico." 